\title{
THE RELATIONSHIP BETWEEN CRIMEAN-CONGO HEMORRHAGIC FEVER AND CLIMATE: DOES CLIMATE AFFECT THE NUMBER OF PATIENTS?
}

\author{
Fazilet Duygu ${ }^{1}$, Tugba Sari ${ }^{1}$, Turan Kaya ${ }^{2}$, Oznur Tavsan ${ }^{2}$ and Murat Naci ${ }^{3}$
}

${ }^{1}$ Public Health Institution of Turkey, Ankara, Turkey;

${ }^{2}$ Tokat State Hospital, Department of Infectious Diseases and Clinical Microbiology, Tokat, Turkey; ${ }^{3}$ Ondokuz Mayis University Faculty of Medicine, Department of Statistics, Samsun, Turkey

\begin{abstract}
SUMMARY - Crimean-Congo hemorrhagic fever (CCHF) is a tick-borne viral zoonosis. The incidence of zoonotic diseases has been shown to be affected by climatic factors. In this study, we evaluated patients endemic to the CCHF region and examined the relationship between the number of patients and climatic properties of the region where they lived. The study included $548 \mathrm{CCHF}$ patients. Along with the patient demographic and clinical characteristics, we recorded temperature, humidity and precipitation in the places where they lived at the time of their admission to the hospital. In addition to temperature, humidity and precipitation at the time of patient admission, these values were assessed at one month and three months prior to admission. The relationship between the number of patients and the above-mentioned values was examined. Humidity at the time of and one month prior to hospital admission, and precipitation three months prior to hospital admission were found to affect the number of patients admitted to the hospital for CCHF. In conclusion, climate appeared to affect the number of $\mathrm{CCHF}$ patients. We believe that the number of patients presenting to the hospital with CCHF could be predicted by taking into account climatic properties of the places where CCHF has been recorded, along with undertaking necessary measures.
\end{abstract}

Key words: Hemorrhagic fever, Crimean-Congo; Climate; Ticks; Zoonoses

\section{Introduction}

The Crimean-Congo hemorrhagic fever (CCHF) is a tick-borne viral zoonotic infectious disease characterized by fever and bleeding, with a potentially fatal outcome. The infectious agent is a single-stranded lipid enveloped RNA virus that belongs to the Bunyaviridae family of the genus Nairovirus. The disease can infect people when the virus is passed into the circulatory system as a result of a bite by ticks of the genus Hyalomma. In addition, transmission may occur as a

Correspondence to: Tugba Sari, MD, Public Health Institution of Turkey, Saglik Mahallesi, Adnan Saygun Cad, No. 55, 06430 Cankaya/Ankara, Turkey

E-mail: drtugba82@gmail.com

Received June 6, 2016, accepted May 4, 2017 result of contact with blood or body fluids of the infected hosts ${ }^{1,2}$. CCHF has been recorded in 52 countries in Africa, Asia, Eastern Europe and the Middle East $^{3}$.

The CCHF symptoms are characterized by a short incubation period followed by a sudden onset of high fever, chills, headache and abdominal pain. In addition, nausea, vomiting, diarrhea, neuropsychiatric and cardiac changes may occur. Hemorrhagic signs ranging from petechiae to large ecchymosis may be observed ${ }^{4}$.

The CCHF is typically observed from April to September, mostly in the Central Anatolian region of Turkey, in the cities of Tokat, Sivas and Yozgat. The climate of this region is moderate rainy and cold during the winters, and hot and dry during the summers, and these conditions are optimal for the survival of the 
Hyalomma type ticks ${ }^{3,4}$. This study was conducted in the city of Tokat, which is the region with the highest incidence of CCHF in Turkey ${ }^{5}$.

In this study, we evaluated 548 patients who were followed during the 2007-2011 period in the Tokat region. We assessed the relationship of the disease with climatic changes, as well as the relationship between the number of patients and temperature, humidity and precipitation.

\section{Patients and Methods}

The patients admitted to the Tokat State Hospital during the 2007-2011 period were hospitalized with clinical and laboratory findings compatible with CCHF. Patient sera were sent to the National Reference Laboratory. A total of 548 patients who were CCHF PCR and/or IgM antibody positive were diagnosed with $\mathrm{CCHF}$ and were included in the study.

The patient admission date, place of residence and clinical characteristics were recorded. Temperature, humidity, and precipitation measured by meteorological stations in the Tokat region in the years 2007-2011 were obtained from the General Directorate of Meteorology of Turkey. Meteorological data from the patient residence were collected on the date of hospital admission, as well as one month and three months before hospital admission.

\section{Statistical analyses}

Categorical variables were defined as percentages and counts, and were analyzed by $\chi^{2}$-test. The normality of distribution of continuous variables was determined by Kolmogorov-Smirnov test. Comparison of continuous variables between two groups was done by two independent sample t-tests or Mann Whitney U test. The mean and standard deviation (SD) or median and interquartile range (Q1-Q3) were used to report continuous variables.

The Poisson regression method was used to examine the factors influencing the number of patients. The relationship between the number of patients with the previous year's temperature, humidity and precipitation was analyzed by the logistic regression analysis.

\section{Results}

We investigated the effects of the following variables on the number of patients: year, month, humidity, humidity 1 (humidity at the patient residence one month before hospital admission), humidity 3 (humidity three months before hospital admission), temperature, temperature 1 (temperature at the patient residence one month before hospital admission), temperature 3 (temperature three months before hospital admission), precipitation, precipitation 1 (precipitation at the patient residence one month before hospital admission), and precipitation 3 (precipitation three months before hospital admission).

We evaluated the relationship between the number of patients and temperature at the time of their admission to the hospital. The number of patients was statistically significantly higher in 2008 versus 2007 $(\mathrm{p}=0.000)$ and in 2009 versus $2007(\mathrm{p}=0.014)$.

Considering the relationship between the number of patients and temperature one month before hospital admission, the number of patients was statistically significantly higher in 2009 as compared with 2008 $(\mathrm{p}=0.043)$.

Evaluation of the relationship between the number of patients and temperature three months before hos-

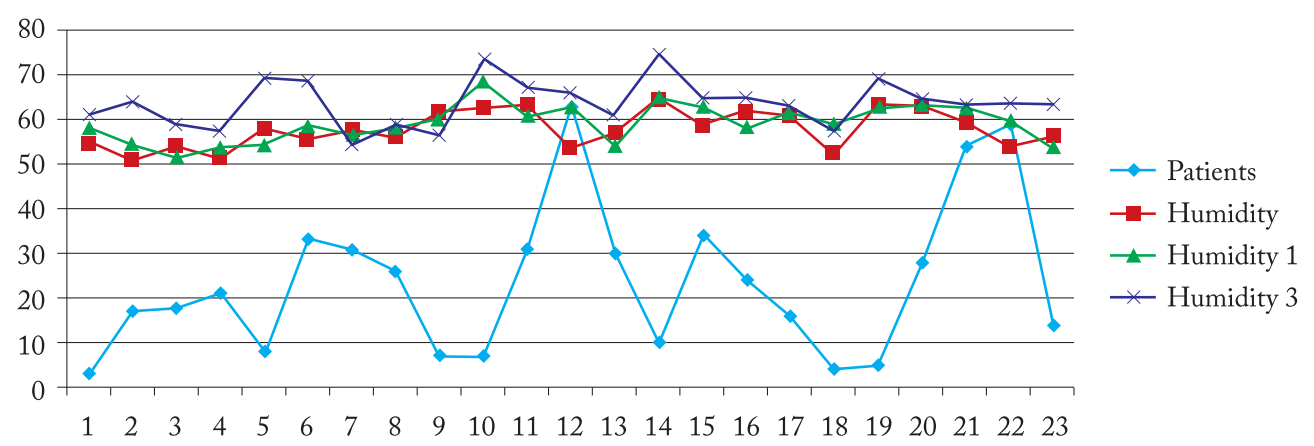

Fig. 1. Relationship between the number of Crimean-Congo hemorrhagic fever patients and humidity. 
pital admission showed the number of patients to be statistically significantly higher in 2010 versus 2007 and in 2008 versus 2010 ( $\mathrm{p}=0.000$ both).

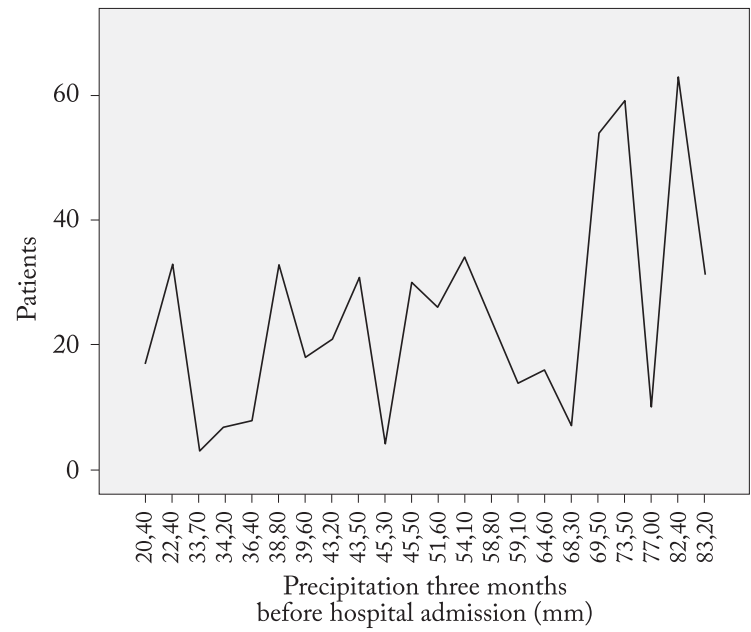

Fig. 2. Relationship between the number of Crimean-Congo hemorrhagic fever patients and level of precipitation three months prior to hospital admission.
Considering the relationship between the number of patients and humidity three months before hospital admission, the number of patients was statistically significantly higher in 2009 versus 2010 and in 2011 versus 2010 ( $\mathrm{p}<0.05$ both) (Fig. 1).

We evaluated the relationship between the number of patients and precipitation at the time of their admission to the hospital. The number of patients was statistically significantly higher in 2009 as compared with 2008 and in 2011 as compared with 2010 ( $<<0.05$ both).

The analysis showed that the humidity levels at the time of patient admission ( $\mathrm{p}=0.000$ ) (Fig. 1) and one month prior to admission ( $\mathrm{p}=0.005)$ (Fig. 1 ), as well as precipitation three months prior to patient admission influenced the number of patients developing $\mathrm{CCHF}$ $(\mathrm{p}=0.000)$ (Fig. 2).

Yearly temperature, humidity and precipitation are shown in Table 1. There was no relationship between the number of patients and previous year's levels of temperature, humidity and precipitation.

Table 1. Number of patients, temperature, bumidity and level of precipitation according to years

\begin{tabular}{|c|c|c|c|c|c|c|}
\hline Year & 2007 & 2008 & 2009 & 2010 & 2011 & $p$ \\
\hline Patients (N) & 59 & 105 & 133 & 95 & 160 & 0.000 \\
\hline Temperature $\left({ }^{\circ} \mathrm{C}\right)$ & $\begin{array}{l}21.7 \\
(20.3 \pm 24.1)\end{array}$ & $\begin{array}{l}19.6 \\
(15.2 \pm 23.1)\end{array}$ & $\begin{array}{l}21.4 \\
(15.6 \pm 21.6)\end{array}$ & $\begin{array}{l}19.65 \\
(18.0 \pm 22.3)\end{array}$ & $\begin{array}{l}19.5 \\
(18.8 \pm 24.2)\end{array}$ & $0.668^{*}$ \\
\hline Temperature $1\left({ }^{\circ} \mathrm{C}\right)$ & $\begin{array}{l}20.3 \\
(9.4 \pm 21.7)\end{array}$ & $\begin{array}{l}15.2 \\
(14.8 \pm 19.6)\end{array}$ & $\begin{array}{l}11.2 \\
(15.6 \pm 15.8)\end{array}$ & $\begin{array}{l}17.3 \\
(12.1 \pm 18)\end{array}$ & $\begin{array}{l}15.5 \\
(14.6 \pm 19.5)\end{array}$ & $0.852^{\mathrm{f}}$ \\
\hline Temperature $3\left({ }^{\circ} \mathrm{C}\right)$ & $\begin{array}{l}7.9 \\
(2.9 \pm 9.4)\end{array}$ & $\begin{array}{l}11.9 \\
(0.0 \pm 14.6)\end{array}$ & $\begin{array}{l}7 \\
(6.6 \pm 7)\end{array}$ & $\begin{array}{l}8.6 \\
(8.6 \pm 9)\end{array}$ & $\begin{array}{l}6.7 \\
(6.7 \pm 10.9)\end{array}$ & $0.677^{\mathrm{h}}$ \\
\hline Humidity (\%) & $\begin{array}{l}50.9 \\
(50.9 \pm 53.5)\end{array}$ & $\begin{array}{l}55.8 \\
(55.7 \pm 57.5)\end{array}$ & $\begin{array}{l}52.2 \\
(52.2 \pm 62.3)\end{array}$ & $\begin{array}{l}60.9 \\
(59.1 \pm 62.4)\end{array}$ & $\begin{array}{l}59.5 \\
(54 \pm 61.8)\end{array}$ & $0.000^{\mathrm{e}}$ \\
\hline Humidity 1 (\%) & $\begin{array}{l}54 \\
(50.9 \pm 54.7)\end{array}$ & $\begin{array}{l}56.7 \\
(55.7 \pm 57.6)\end{array}$ & $\begin{array}{l}62.3 \\
(52.2 \pm 62.3)\end{array}$ & $\begin{array}{l}62.4 \\
(59.1 \pm 63.3)\end{array}$ & $\begin{array}{l}62.2 \\
(59.5 \pm 63)\end{array}$ & $0.005^{\mathrm{e}}$ \\
\hline Humidity 3 (\%) & $\begin{array}{l}61.5 \\
(58.5 \pm 64.1)\end{array}$ & $\begin{array}{l}57.6 \\
(57.05 \pm 68.3)\end{array}$ & $\begin{array}{l}65.2 \\
(60.1 \pm 65.2)\end{array}$ & $\begin{array}{l}64.3 \\
(63.4 \pm 65)\end{array}$ & $\begin{array}{l}63.2 \\
(63.0 \pm 63.8)\end{array}$ & $0.833^{t}$ \\
\hline Precipitation $(\mathrm{mm})$ & $\begin{array}{l}31.7 \\
(0.2 \pm 33.8)\end{array}$ & $\begin{array}{l}34.2 \\
(6.65 \pm 53.7)\end{array}$ & $\begin{array}{l}45.5 \\
(20.0 \pm 60.1)\end{array}$ & $\begin{array}{l}45.3 \\
(45.3 \pm 59.8)\end{array}$ & $\begin{array}{l}59.1 \\
(37.9 \pm 76.4)\end{array}$ & $0.142^{\epsilon}$ \\
\hline Precipitation $1(\mathrm{~mm})$ & $\begin{array}{l}33.8 \\
(31.7 \pm 43.2)\end{array}$ & $\begin{array}{l}51.6 \\
(34.2 \pm 52.65)\end{array}$ & $\begin{array}{l}60.1 \\
(45.5 \pm 60.1)\end{array}$ & $\begin{array}{l}59.8 \\
(45.3 \pm 64.6)\end{array}$ & $\begin{array}{l}73.5 \\
(59.1 \pm 76.4)\end{array}$ & $0.264^{\mathrm{e}}$ \\
\hline Precipitation $3(\mathrm{~mm})$ & $\begin{array}{l}39.6 \\
(20.4 \pm 43.2)\end{array}$ & $\begin{array}{l}43.5 \\
(38.8 \pm 47.55)\end{array}$ & $\begin{array}{l}82.4 \\
(68.3 \pm 82.4)\end{array}$ & $\begin{array}{l}58.8 \\
(54.1 \pm 64.6)\end{array}$ & $\begin{array}{l}69.5 \\
(59.1 \pm 73.5)\end{array}$ & $0.000^{e}$ \\
\hline
\end{tabular}

*Statistically significant difference between 2007 and 2008 ( $\mathrm{p}=0.000)$, and between 2007 and 2009 ( $\mathrm{p}=0.014$ ). There was no statistically significant difference among other groups; ${ }^{\mathrm{f}}$ statistically significant difference between 2008 and 2009 ( $\mathrm{p}=0.043$ ); ${ }^{\mathrm{h}}$ statistically significant difference between 2007 and 2010, and between 2008 and 2010 ( $\mathrm{p}=0.000$ both); ${ }^{\mathrm{e}}$ statistically significant difference among all groups ( $\mathrm{p}=0.000)$; ${ }^{\mathrm{t}}$ no statistically significant difference between 2007 and 2008, 2008 and 2009. There was a statistically significant difference among other groups $(\mathrm{p}<0.05)$; fno statistically significant difference between 2009 and 2010. There was a statistically significant difference among other groups $(\mathrm{p}<0.05)$. 


\section{Discussion}

This was the first study to examine the relationship between climate and the incidence of CCHF. We found climate to have an effect on the occurrence of CCHF. Elevated levels of humidity at the time of patient admission to the hospital and one month prior to that time point, along with the increased precipitation three months prior to hospital admission were shown to escalate the incidence of CCHF.

The CCHF is a zoonotic viral disease that is initiated by the tick-borne Nairovirus virus. The Hyalomma tick is the vector responsible for viral transmission of the disease and has a wide distribution, which correlates with the global distribution of CCHF. The disease is usually asymptomatic in animals, but can cause death in 5\%-30\% of humans ${ }^{1}$. After the incubation period of 3-7 days, CCHF shows the following symptoms: high fever, myalgia, nausea, vomiting, headache, abdominal pain and diarrhea. In addition, hypotension, relative bradycardia, tachypnea, conjunctivitis, pharyngitis and cutaneous flushing or rash can occur. The disease is observed from April to September and peaks in June and July ${ }^{6}$. In this study, it was shown that $\mathrm{CCHF}$ emerged during the period from March to October.

Climatic factors have an important role in the incidence of vector-borne diseases. The incidence of Lyme disease has been also shown to be affected by climatic changes ${ }^{3}$.

The CCHF is most commonly observed in the Central Anatolian region in Turkey (Tokat, Sivas, Yozgat, and the surrounding area), where the summers are hot and dry and winters are cold and moderately rainy. This climate is suitable for optimal survival of Hyalomma genus ticks ${ }^{7}$. This study was conducted in Tokat, where CCHF is observed endemically in Turkey.

In the areas where CCHF is endemic, an increase in temperature compared to 10 years before has been reported; especially in the month of April, the increase was greater than $5{ }^{\circ} \mathrm{C}$. It is known that temperature changes influence the tick abundance and length of life. Therefore, we thought that temperature could have an effect on the recent increase in the number of patients diagnosed with $\mathrm{CCHF}^{3,8}$.

It has been reported that climatic changes in Turkey affect the migration patterns of birds and that migratory birds may have a role in the spread of $\mathrm{CCHF}^{2}$.
A change in the population of migratory birds and animals, as well as the structure of the land affect the tick population. Climatic and environmental changes play a role in the diffusion of the virus in Turkey, but complex and different multifactorial reasons may also be involved in the viral diffusion process ${ }^{2,9}$. However, climate emerges as the most important factor when considering all the possible affects.

There have been many studies on the relationship between climatic changes and increase in the incidence of certain infectious diseases ${ }^{10-12}$. Climatic conditions have been suggested to affect the population of ticks and therefore tick-borne diseases ${ }^{12,13}$. However, there has not been a study examining the impact of climate change on $\mathrm{CCHF}$.

In this study, we evaluated not just the general regional data, but also the specific meteorological data from patient areas of residence. We observed the relationship between climate and the number of $\mathrm{CCHF}$ patients. The increase in the number of CCHF patients was observed in Tokat and its surroundings, and this study showed that climate might be a reason for the increased number of these patients.

Zhang et al. report on a relationship between temperature and precipitation and the incidence of hemorrhagic fever with renal syndrome ${ }^{14}$. It has also been reported that climatic changes affected dispersion of Phlebotomus spp., as well as dispersion of $P$. mascittii and Leishmania infantum vector, which causes leishmaniasis ${ }^{15}$.

One study showed that humidity levels from previous two years were associated with the incidence of Lyme disease. It was suggested that dry and hot air could kill nymph eggs and that two years after a dry summer there would be a decrease in the number of ticks ${ }^{3}$. On the other hand, two different studies showed that one and two years after a rainy summer, there was an increase in the number of ticks ${ }^{16,17}$. In another study related to Lyme disease, it is reported that temperature in the winter season from the same year did not affect the incidence of Lyme disease. Nevertheless, the incidence was found to be increased in relation to the previous year's winter temperature. It was not specified whether this increase in the disease incidence was due to an increase in the population of ticks or increase in the number of rodents ${ }^{18}$.

The $2{ }^{\circ} \mathrm{C}$ increase in winter temperature in the New England region has been reported to increase the sur- 
vival chances of Peromyscus leucopus species, thus increasing the incidence of Lyme disease in that region ${ }^{19}$. Warm winters and humid springs have been reported to increase the incidence of Lyme disease two years later ${ }^{3}$.

Tick-borne encephalitis (TBE) is an increasing burden for healthcare systems in many Arctic countries $^{20-22}$. Heat and humidity have great importance in the life cycle of Ixodes ticks. Climatic changes were shown to alter the habitat of Ixodes ticks, which carry TBE vectors ${ }^{23}$. These studies investigated the effects of climate on ticks that play a role in dispersion of different diseases. In our study, we investigated the effect of climate on the incidence of $\mathrm{CCHF}$ patients.

\section{Conclusion}

We found that the levels of humidity in the month of emergence of the disease and one month prior to that time point, along with precipitation three months before increased the number of patients diagnosed with $\mathrm{CCHF}$. Based on these results, we suggest that the number of CCHF patients be predicted by considering climate in the regions where $\mathrm{CCHF}$ is observed, so that necessary measures can be taken.

\section{References}

1. Whitehouse CA. Crimean-Congo hemorrhagic fever. Antiviral Res. 2004;64:145-60.

2. Leblebicioglu H. Crimean-Congo haemorrhagic fever in Eurasia. Int J Antimicrob Agents. 2010;36(Suppl 1):43-6. doi: 10.1016/j.ijantimicag.2010.06.020.

3. Subak S. Effects of climate on variability in Lyme disease incidence in the northeastern United States. Am J Epidemiol. 2003;157:531-8.

4. Suma B, Appannanavar, Mishra B. An update on Crimean Congo hemorrhagic fever. J Global Infect Dis. 2011;3:285-92. doi: 10.4103/0974-777X.83537

5. Yilmaz GR, Buzgan T, Irmak H, Safran A, Uzun R, Cevik $\mathrm{MA}$, et al. The epidemiology of Crimean-Congo hemorrhagic fever in Turkey, 2002-7. Int J Infect Dis. 2009;13:380-6. doi: 10.1016/j.ijid.2008.07.021.

6. Hoogstraal H. The epidemiology of tick-borne Crimean-Congo hemorrhagic fever in Asia, Europe and Africa. J Med Entomol. 1979;15:307-417.

7. Kocaman I, Akgunduz S. Tokat Sivas ve Yozgat illerinde gorulen Kirim Kongo Kanamali Atesi hastaligini yayilimi ve sicaklik degisikliginden etkilenisi. Dort Mevsim Meteoroloji Bulteni. 2006;2:37-40. (in Turkish)

8. Ozdarendeli A, Aydin K, Tonbak S, et al. Genetic analysis of the MRNA segment of Crimean-Congo hemorrhagic fever virus strains in Turkey. Arch Virol. 2008;153:37-44.. doi: 10.1007/s00705-007-1056-4

9. Herst RW. Global change and human vulnerability to vectorborne diseases. Clin Microbiol Rev. 2004;17:136-73.

10. Hay SI, Cox J, Rogers DJ, Randolph SE, Stern DI, Shanks $\mathrm{GD}$, et al. Climate change and the resurgence of malaria in the east African highlands. Nature. 2002;415:905-9. doi: $10.1038 / 415905 \mathrm{a}$

11. Gubler DJ, Reiter P, Ebi KL, Yap W, Nasci R, Patz JA. Climate variability and change in the United States: potential impacts on vector- and rodent-borne diseases. Environ Health Perspect. 2001;109:223-33. doi: 10.1289/ehp.109-1240669

12. Lindgren E, Gustafson R. Tick-borne encephalitis in Sweden and climate change. Lancet. 2001;358:16-8. doi: 10.1016/ S0140-6736(00)05250-8

13. Estrada-Pena A. Forecasting habitat suitability for ticks and prevention of tick-borne diseases. Vet Parasitol. 2001;98: 111-32.

14. Zhang W, Guo WD, Fang LQ, Li CP, Bi P, Gregory E, et al. Climate variability and hemorrhagic fever with renal syndrome transmission in northeastern China. Environ Health Perspect. 2010;118:915-20. doi: 10.1289/ehp.0901504

15. Fischer D, Moeller P, Thomas SM, Naucke TJ, Beierkuhnlein C. Combining climatic projections and dispersal ability: a method for estimating the responses of sandfly vector species to climate change. Plos Neglect Trop Dis. 2011;5:1407. doi: 10.1371/journal.pntd.0001407

16. Jones CG, Kitron UD. Populations of Ixodes scapularis (Acari: Ixodidae) are modulated by drought at a Lyme disease focus in Illinois. J Med Entomol. 2000;37:408-15. doi: 10.1603/0022-2585(2000)037[0408:POISAI]2.0.CO;2

17. Ostfeld RS, Schauber EM, Canham CD, et al. Effects of acorn production and mouse abundance on abundance and Borrelia burgdorferi infection prevalence of nymphal Ixodes scapularis ticks. Vector Borne Zoon Dis. 2001;1:55-63. doi: 10.1089/153036601750137688

18. Mather TN, Nicholson MC, Donnelly EF, et al. Entomological risk index for human risk of Lyme disease. Am J Epidemiol. 1996;144:1066-9.

19. Keim B, Rock B. The New England region's changing climate. Foundation document. Potential consequences of climate variability and change for the U.S. Washington, DC: US Global Research Program, 2001.

20. Zygutiene M. Tick-borne encephalitis - the most relevant to public health flavivirus infection in the EpiNorth region. EpiNorth. 2011;12:31-2.

21. Jaaskelainen A, Korhonen T, Kuusi M, Vapalahti O. Tickborne encephalitis in Finland. EpiNorth. 2011;12:40-3.

22. Glushkova L, Galimov R. Ecological and epidemiological aspects of tick-borne encephalitis in the Republic of Komi and disease prevention. EpiNorth. 2011;12:44-50.

23. Jaenson TGT, Tälleklint L, Lundqvist L, Olsen B, Chirico J, Mejlon H. Geographical distribution, host associations, and vector roles of ticks (Acari: Ixodidae, Argasidae) in Sweden. J Med Entomol. 1994;31:240-56. 


\title{
Sažetak \\ ODNOS KRIMSKO-KONGOANSKE HEMORAGIJSKE GROZNICE I KLIME: UTJEČE LI KLIMA NA BROJ OVIH BOLESNIKA?
}

\author{
F. Duygu, T. Sari, T. Kaya, O. Tavsan i M. Naci
}

Krimsko-kongoanska hemoragijska groznica (KKHG) je virusna zoonoza koju prenose krpelji. Dokazano je da klimatski čimbenici utječu na incidenciju zoonotskih bolesti. U ovom smo istraživanju ispitivali bolesnike endemske za područje KKHG te odnos broja bolesnika i klimatskih svojstava područja u kojem oni žive. U istraživanje je bilo uključeno 548 bolesnika s KKHG. Uz demografske i kliničke značajke bolesnika bilježili smo temperaturu, vlagu i količinu padalina u mjestu gdje su bolesnici živjeli u vrijeme prijma u bolnicu. Uz vrijednosti temperature, vlage i količine padalina u vrijeme prijma bolesnika u bolnicu, vrijednosti ovih parametara procijenjene su za jedan mjesec i tri mjeseca prije prijma u bolnicu. Tada smo ispitali odnos broja bolesnika i gore spomenutih vrijednosti. Pokazalo se da razina vlage u vrijeme prijma i jedan mjesec prije prijma u bolnicu, kao i količina padalina tri mjeseca prije prijma u bolnicu utječu na broj bolesnika primljenih u bolnicu zbog KKHG. U zaključku, čini se da klima utječe na broj bolesnika s KKHG. Vjerujemo da bi se broj bolesnika koji dolaze u bolnicu zbog KKHG mogao predvidjeti uzimajući u obzir klimatska svojstva u mjestima gdje je zabilježena KKHG, a time bi se isto tako mogle poduzeti odgovarajuće mjere.

Ključne riječi: Krimsko-kongoanska hemoragijska groznica; Klima; Krpelji; Zoonoze 